\title{
THE VALUE OF CHARACTER EDUCATION BASED ON HISTORY OF THE MATARAM KUNO KINGDOM IN THE 8TH-9TH AD
}

\author{
Naufal Raffi Arrazaq \\ Fakultas Ilmu Sosial, Universitas Negeri Yogyakarta \\ naufalraffi197@gmail.com
}

\begin{abstract}
Abstrak
Mataram Kuno merupakan kerajaan bercorak Hindu Buddha yang berkembang abad VIII-X Masehi. Kerajaan Mataram Kuno memiliki beberapa peninggalan sejarah. Salah satu wilayah yang menyimpan peninggalan sejarah Kerajaan Mataram Kuno adalah Kabupaten Magelang. Peninggalan sejarah yang ditemukan berupa candi, arca, dan prasasti. Tujuan dari penelitian ini adalah menganalisis corak pendidikan dan nilai pendidikan karakter berdasarkan sejarah Kerajaan Mataram Kuno abad VIII-X Masehi. Penelitian ini menggunakan metode penelitian sejarah menurut Kuntowijoyo, dengan tahapan yaitu: (1) pemilihan topik, (2) pengumpulan sumber, (3) kritik sumber, (4) interpretasi, (5) penulisan sejarah. Hasil dari penelitian ini yaitu, pendidikan di Kerajaan Mataram Kuno bercorak keagamaan. Hasil dari kegiatan pendidikan tersebut berupa pengetahuan di bidang keagamaan dan penanggalan atau astronomi. Nilai pendidikan karakter yang dapat dipelajari adalah local genius dan toleransi yang diwujudkan dalam bangunan candi. Nilai pendidikan karakter selanjutnya adalah kesetaraan gender. Berdasarkan prasasti yang ditemukan di Kabupaten Magelang dapat diketahui adanya pejabat perempuan di tingkat wanua.
\end{abstract}

Kata Kunci: Pendidikan karakter, Mataram Kuno, Sejarah

\begin{abstract}
The Mataram Kuno Kingdom is a thriving Buddhist Hindu in 8th-9th centuries AD. The Mataram Kuno Kingdom has some historical relics. One area which houses historical relics of Mataram Kuno Kingdom is Magelang Regency. Historical heritage that is found in the form of temples, statues, and inscriptions. The purpose of this research is to analyze the pattern of education and character education based on the history of the Mataram Kuno Kingdom in 8th-9th centuries $A D$. This research uses the methods of historical research, according to Kuntowijoyo, by stages, namely: (1) selection of topics, (2) the collection of sources, (3) source criticism, (4) interpretation, (5) writing of history. The results of this study, namely, education in the religious institution of the ancient Mataram Kingdom. The result of these educational activities in the form of knowledge in the field of religious and astronomical or calendar. The value of character education that can be learned is local genius and tolerance is manifested in temple building. The value of the next character education was gender equality. Based on inscriptions found in Magelang Regency knowable existence of women officials at the level of wanua.
\end{abstract}

Keywords: character education, the ancient Mataram, history 


\section{PENDAHULUAN}

Sejarah merupakan ilmu yang dapat digunakan sebagai sumber pembelajaran karakter. Sumber pembelajaran tersebut dapat diperoleh melalui peninggalan sejarah dan peristiwa sejarah. Peninggalan sejarah merupakan sumber sejarah yang keberadaannya dapat dijumpai di berbagai tempat. Pemanfaatan peninggalan sejarah sebagai sumber pembelajaran karakter dapat membuat generasi muda memiliki ketertarikan terhadap mata pelajaran sejarah.

Materi pelajaran sejarah mampu mengembangkan potensi peserta didik untuk mengenal nilainilai bangsa yang diperjuangkan pada masa lalu, dipertahankan dan disesuaikan untuk kehidupan masa kini, dan dikembangkan lebih lanjut untuk kehidupan masa depan (Hasan, 2012). Generasi masa kini dapat mempelajari kehidupan masyarakat di masa lampau melalui sejarah. Keberhasilan masyarakat di masa lampau dapat ditarik relevansinya pada masa kini.

Salah satu sumber peninggalan sejarah berasal dari masa Kerajaan Mataram Kuno. Kerajaan Mataram Kuno dapat diketahui berdasarkan Prasasti Canggal yang ditemukan di Desa Kadiluwih. Prasasti ini berasal dari tahun 732 Masehi, ditulis dengan huruf Pallawa dan digubah dalam bahasa Sanskerta. Isinya memperingati didirikannya sebuah lingga (lambang Dewa Siwa) di atas sebuah bukit di daerah Kunjarakunja oleh raja Sanjaya. Daerah ini letaknya di sebuah pulau yang mulia, Yawadwipa, yang kaya raja akan hasil bumi, terutama padi dan emas (Soekmono, 1973).

$$
\text { Peninggalan sejarah }
$$

Kerajaan Mataram Kuno tersebar di berbagai wilayah. Salah satu wilayah yang memiliki peninggalan Kerajaan Mataram Kuno adalah Kabupaten Magelang. Di Kabupaten Magelang ditemukan bangunan candi, arca, dan prasasti peninggalan Kerajaan Mataram Kuno. Peninggalan sejarah tersebut 
dapat memberikan informasi mengenai corak pendidikan masa Kerajaan Mataram Kuno dan dapat digunakan sebagai sumber pembelajaran karakter. Tujuan dari penelitian ini adalah mengidentifikasi corak pendidikan masa Kerajaan Mataram Kuno. Tujuan selanjutnya untuk mengetahui nilai pendidikan karakter berdasarkan sejarah Kerajaan Mataram Kuno.

\section{METODE}

Penelitian ini menggunakan metode sejarah kritis menurut Kuntowijoyo. Tahapan penelitian sejarah menurut Kuntowijoyo (2013) terdiri dari lima tahapan yaitu, 1) pemilihan topik, 2) pengumpulan sumber, 3 ) verifikasi (kritik sumber), 4) interpretasi (analisis dan sintesis), 5) historiografi (penulisan sejarah). Penggunaan metode penulisan sejarah kritis tersebut, karena penelitian ini merupakan penelitian sejarah. Kelima tahapan penelitian sejarah tersebut akan diuraikan sebagai berikut.

\section{a. Pemilihan Topik}

Pemilihan topik dalam penelitian ini terdiri dari kedekatan emosional dan intelektual. Kedekatan emosional karena peneliti pernah tinggal di Kabupaten Magelang selama enam tahun. Selama tinggal di Kabupaten Magelang peneliti sering berkunjung ke situs peninggalan Kerajaan Mataram Kuno. Pendekatan intelektual dilatarbelakangi oleh mata kuliah Sejarah Indonesia masa Hindu dan Buddha yang ada di Program Studi Pendidikan Sejarah, Fakultas Ilmu Sosial, Universitas Negeri Yogyakarta.

\section{b. Heuristik}

Pengumpulan sumber berupa dokumen atau buku dalam penelitian ini diperolah dari perpustakaan. Sumber berupa bangunan candi diperoleh dengan melakukan observasi pada situs candi yang ada di Kabupaten Magelang. Sumber berupa temuan lepas berupa prasasti dan arca diperoleh dengan observasi di Museum Balai Pelestarian Cagar 
Budaya Jawa Tengah dan Museum Nasional Jakarta. Sumber yang digunakan dalam penelitian ini adalah sumber primer dan sumber sekunder yang berupa prasasti, arca, candi, dan buku pendukung.

1) Sumber Prasasti

Prasasti Canggal, tahun 654 Saka

Prasasti Kamalagi, tahun 743 Saka

Prasasti Kurambitan, tahun 791

Saka

Prasasti Plandi, tahun 791 Saka

Prasasti Mulak, tahun 800 Saka

Prasasti Kwak I, tahun 801 Saka

Prasasti Kwak II, tahun 801 Saka

Prasasti Ratawun, tahun 802 Saka

Prasasti Ramwi, tahun 804 Saka

Prasasti Munggu Antan, tahun 808 Saka

Prasasti Poh Dulur, tahun 812 Saka

Prasasti Palepanan, tahun 828 Saka

Prasasti Tihang, tahun 836 Saka

2) Sumber Artefak

Sumber artefak berupa bangunan candi dan arca yang ditemukan di Kabupaten Magelang, Provinsi Jawa Tengah. Bangunan candi dan arca tersebut dianalisis untuk mengetahui corak pendidikan dan nilai pendidikan karakter berdasarkan sejarah Kerajaan Mataram Kuno abad VIIIX Masehi.

\section{c. Kritik Sumber (Verifikasi)}

Kritik sumber yang dilakukan dalam penelitian ini adalah kritik internal dan kritik eksternal. Kritik internal dilakukan dengan melihat isi dari sumber sejarah. kritik eksternal dilakukan dengan cara pengecekan kondisi fisik sumber sejarah.

\section{d. Interpretasi}

Fakta sejarah yang telah diperoleh dari tahap verifikasi merupakan bukti dari peristiwa sejarah. Antar fakta sejarah tersebut dicari hubungannya sehingga menjadi satu kesatuan yang utuh. Interpretasi isi prasasti menggunakan metode epigrafi. Bangunan candi dan arca dengan metode ikonografi.

\section{e. Historiografi}

Tahap

historiografi dilakukan dengan menulis faktafakta sejarah dengan kronologis sesuai dengan data yang diperoleh. Penyajian tulisan sejarah terdiri 
dari pendahuluan, pembahasan, dan kesimpulan.

\section{HASIL DAN PEMBAHASAN}

\section{A. Pendidikan Masa Kerajaan Mataram Kuno}

Sistem pendidikan dan pengajaran telah dikenal masyarakat Jawa Kuna, terlihat dari cerita-cerita yang terpahat pada dinding candi, cerita-cerita dalam pertunjukkan wayang karya sastra. Semua cerita itu meskipun telah diubah, diganti, ditambah, atau dikurangi, namun tetap mengandung maksud pendidikan yang mementingkan budi pekerti (Wirasanti, 1997).

Sistem pendidikan dapat diketahui berdasarkan peninggalan sejarah. Peninggalan Kerajaan Mataram Kuno abad VIII-X Masehi di Kabupaten Magelang berupa bangunan candi dan prasasti. Peninggalan sejarah tersebut menunjukkan adanya peradaban yang sudah terstruktur. Peninggalan sejarah berupa bangunan candi dan prasasti memberikan informasi bahwa masyarakat Kerajaan Mataram Kuno sudah mengenal pendidikan. Masa Hindu dan Buddha dikenal beberapa sumber data yang dapat digunakan untuk menyingkap berbagai segi kehidupan di zamannya, antara lain segi kegiatan pendidikan. Sumber tertulis berupa prasasti dan karya sastra. Sumber penunjang berupa relief pada candi. Kadang-kadang dalam relief menggambarkan situasi belajar mengajar (Sedyawati, Zainuddin, \& Wuryantoro, 1991). Di Kabupaten Magelang ditemukan sumber sejarah berupa bangunan candi dan prasasti yang dapat memberikan informasi mengenai pendidikan masyarakat pada abad VIII-X Masehi.

Kehidupan masyarakat Kerajaan Mataram Kuno abad VIII$\mathrm{X}$ Masehi yang terstruktur mengindikasikan adanya kegiatan pendidikan. Terdapat kelompok masyarakat brahmana, ksatria, waisya, dan sudra. Kedudukan kelompok brahmana lebih tinggi dari kelompok lainnya, karena 
mememiliki pengetahuan yang mendalam tentang keagamaan (Sedyawati, Zainuddin, \& Wuryantoro, 1991). Brahmana memiliki peran untuk mengajarkan hal-hal yang berkaitan dengan masalah keagamaan.

Bukti pendidikan keagamaan yang dilakukan oleh brahmana adalah pembangunan bangunan suci berupa candi. Pendirian bangunan suci berupa candi memerlukan pengetahuan di bidang keagamaan. Pengetahuan di bidang pendidikan tersebut diajarkan oleh brahmana. Menurut Munandar para pekerja bukan tukang bangunan biasa, melainkan para slipin (pendeta seniman) yang bertugas mendirikan bangunanbangunan suci (Munandar, 2015). Pembangunan bangunan suci memerlukan pengetahuan dan keterampilan yang diperoleh dari proses belajar.

Berdasarkan data kitab Manasara-Silpasastra terdapat enam macam orang/kelompok orang yang berperan dalam pembangunan candi. Ke enam orang tersebut adalah yajaman, sthapaka, sthapati, sutragrahin, taksaka, wardhakin (Munandar, 2015). Pendirian bangunan candi memerlukan keahlian khusus di bidang keagamaan. Bangunan candi sebagai sarana ritual keagamaan tidak boleh sembarangan dibangun. Pembangunan tersebut harus memerhatikan konsep keagamaan Hindu dan Buddha.

Golongan brahmana sebagai orang yang mengetahui agama Hindu dan Buddha merupakan seorang guru. Brahman tersebut mengajarkan konsep keagamaan Hindu dan Buddha kepada murid atau siswa. Keberadaan guru dan aktivitas pendidikan pada prasasti Kerajaan Mataram Kuno abad VIIIX Masehi di Kabupaten Magelang tidak disebutkan. Peninggalan berupa candi dan prasasti yang ditemukan di Kabupaten Magelang hanya memberikan data mengenai hasil dari kegiatan pendidikan.

Hasil dari kegiatan pendidikan pada masa Kerajaan Mataram Kuno abad VIII-X Masehi 
yang ditemukan di Kabupaten Magelang berupa pengetahuan masyarakat. Sebagai contoh masyarakat Kerajaan Mataram Kuno abad VIII-X Masehi sudah mengenal astronomi atau penanggalan. Data mengenai astronomi atau penanggalan terdapat dalam prasasti. Berikut merupakan kutipan prasasti yang memuat data mengenai astronomi atau panggalan.

Prasasti Kamalagi Tahun 754 Saka Sisi Depan Baris 1-4

1. // swasti śaka warșâtī

2. ta 753 māsa waișā

3. kha krsnapakșa tithi daśa

4. mi wāra tu wa ${ }^{\circ}$ aj tatkāla say pamgat

Terjemahan:

1. // Selamat tahun Śaka yang telah berlalu

2. 753 (tahun) hari Selasa Wage,

3. paringkelan Tunglai [tu $w a$ ang], tanggal 10 paro gelap bulan Waișāk

4. ketika [tatkāla] (pejabat) Sang Pamgat (di)... (Wurjantoro, 2012: 7-8)

Prasasti Ramwi Tahun 804 Saka Ia Baris 1

...1.swasti śakawarșâtīta 804 caitra māsa. tithi șașți śuklapakṣa tuplay.

pahin. wṛhaspati. nakșatra puśya.

yoga nya waidhrti. uttara sthana....

Terjemahan:

...1Selamat tahun Śaka yang telah berlalu 804 (tahun), hari Kamis Pahing paringkelan Tunglai tanggal 6 paroterang paroterang bulan Caitra, Nakșatranya Pusya, Yoganya Waidhriti, Sthananya

Uttara...(Wurjantoro, 2018: 376-378).

Berdasarkan Prasasti Kamalagi 754 Saka dan Prasasti Ramwi 804 Saka menunjukkan bahwa masyarakat Kerajaan Mataram Kuno sudah mengenal penanggalan. Prasasti Kamalangi ditetapkan pada hari Selasa Wage, paringkelan Tunglai, tanggal 10 paro gelap bulan Waișāk. Prasasti Ramwi ditetapkan pada hari Kamis Pahing paringkelan Tunglai tanggal 6 bulan Caitra. Kedua prasasti tersebut menunjukkan bahwa masyarakat Kerajaan Mataram Kuno sudah mengenal penanggalan. Pengetahuan mengenai penanggalan diperoleh 
oleh masyarakat sebagai hasil dari pendidikan.

\section{B. Nilai Pendidikan Karakter Berdasarkan Sejarah Kerajaan Mataram Kuno Abad VIII-X Masehi}

Pendidikan karakter dapat dimaknai sebagai pendidikan nilai, pendidikan budi pekerti, pendidikan moral, pendidikan watak, yang bertujuan mengembangkan kemampuan siswa untuk memberikan keputusan baik buruk, memelihara kebaikan, mewujudkan dan menebar kebaikan dalam kehidupan sehari-hari dengan sepenuh hati (Setiawati, 2017). Sejarah Kerajaan Mataram Kuno abad VIII-X Masehi dapat digunakan sebagai sumber pembelajaran bagi siswa. Peninggalan tersebut memuat nilai-nilai karakter yang dapat diterapkan pada kehidupan masa kini. Nilai pendidikan karakter tersebut terdiri dari local genius, toleransi, dan kesetaraan gender. Berikut penjelasan nilai-nilai pendidikan karakter.

\section{Local Genius}

Local genius adalah kepribadian budaya suatu bangsa, yang mengakibatkan bahwa bangsa bersangkutan menjadi lebih mampu menyerap dan mengolah pengaruh kebudayaan yang mendatanginya dari luar wilayah sendiri, sesuai dengan watak dan kebutuhan pribadinya. Mampu menyerap apa yang cocok, dan menolak apa yang tidak cocok baginya (Soebadio, 1986). Local genius dapat diartikan sebagai gerak dinamis suatu masyarakat dalam proses pembentukan budaya akibat pengaruh-pengaruh dari luar. Hasil dari proses ini berupa hal-hal yang mengandung unsurunsur pengaruh dari luar yang telah disesuaikan dengan konsep yang berlaku bagi masyarakat bersangkutan (Soejono 1986). Local genius merupakan kemampuan suatu masyarakat dalam mengolah pengaruh budaya lokal dan disesuaikan dengan budaya setempat.

Local genius dapat dipelajari berdasarkan sejarah Kerajaan 
Mataram Kuno abad VIII-X Masehi.

Sikap local genius telah diterapkan oleh leluhur masyarakat Nusantara. Masyarakat Nusantara dalam menerima pengaruh budaya asing (India) kemudian tidak sepenuhnya menerima konsep tersebut. Terdapat upaya untuk menyesuaikan konsep tersebut terhadap budaya asli. Sebagai contoh bangunan candi merupakan hasil budaya yang konsepnya berasal dari India. Perwujudan pembangunan candi yang ada di Nusantara dan di India memiliki perbedaan. Perbedaan tersebut merupakan bukti adanya sikap local genius.

Candi yang ada di Nusantara kasusnya Jawa memiliki perbedaan dengan candi yang ada di India. Perbedaan tersebut terlihat dari susunan arca dewa yang berada pada percandian. Susunan arca candi bercorak Hindu (Siwa) di Jawa terdapat Dewa Agastya. Agastya diletakan pada relung selatan candi. Di India Dewa Agastya tidak diletakan pada relung percandian Siwa. $\begin{array}{lrr}\text { Pengarcaan } & \text { Dewa } & \text { Agastya } \\ \text { merupakan } & \text { bentuk } & \text { dari }\end{array}$ penyesuaian unsur budaya leluhur masyarakat Nusantara. Keberadaan Agastya tercatat dalam Kitab Agastyaparwa.

Penggambaran relief candi yang ada di Nusantara khususnya Jawa menceritakan kehidupan sehari-hari masyarakat. Sebagai contoh relief yang ada di Candi Borobudur menggambarkan kehidupan masyarakat dalam membuat gerabah. Berdasarkan data etnoarkeologi yang ada pada masyarakat sekitar Candi Borobudur aktivitas pembuatan gerabah masih dilakukan. Aktivitas pembuatan gerabah tersebut dilakukan oleh masyarakat Dusun Klimpoh, Desa Karanganyar, Kecamatan Borobudur, Kabupaten Magelang. Aktivitas pertanian masih dilakukan oleh masyarakat yang berada di sekitar Candi Borobudur, Kabupaten Magelang. Secara konstruksi bangunan candi di Nusantara khususnya Jawa dibangun dengan konstruksi batu bertakik atau sistem kuncian. 
Konstruksi batu bertakik tersebut merupakan wujud adaptasi masyarakat pada waktu itu terhadap kondisi geografis Nusantara. secara geografis Nusantara terletak di wilayah yang memiliki potensi gempa bumi. Penggunaan konstruksi batu bertakik pada bangunan candi memungkinkan batu tersebut tetap mengunci ketika diguncang gempa.

\section{Toleransi}

Toleransi antar umat beragama, yaitu sikap maupun perilaku terhadap hal-hal yang bersifat keagamaan meliputi: keyakinan, pemikiran maupun perilaku keagamaan umat beragama yang mencerminkan toleransi terhadap umat beragama lain baik perorangan maupun kelompok (Khalikin \& Fathur (Ed), 2016). Toleransi agama diartikan sebagai sikap menghormati perbedaan keyakinan dalam suatu komunitas atau masyarakat. Sikap toleransi memungkinkan masyarakat yang berlainan kepercayaan, tetap dapat melakukan ritual peribadatan maupun membangun sarana peribadatan. Sikap toleransi dapat diketahui berdasarkan bukti peninggalan sejarah suatu masyarakat pada periode tertentu. Sikap toleransi dapat dipelajari berdasarkan sejarah Kerajaan Mataram Kuno abad VIIIX Masehi. Kerajaan Mataram Kuno merupakan kerajaan yang bercorak Hindu dan Buddha. Pemeluk agama Hindu dan Buddha dapat menjalankan ritual keagamaan masing-masing. Sikap tersebut mencerminkan adanya toleransi antar umat beragama Hindu dan Buddha pada masa Kerajaan Mataram Kuno. Bukti sejarah yang menguatkan adanya sikap toleransi adalah pendirian sarana peribadatan bercorak Hindu dan Buddha di Kabupaten Magelang dibangun dengan jarak berdekatan. Sebagai contoh di sekitar Candi Borobudur ditemukan situs bercorak Hindu (Yoni Kanggan Wringinputih).

Sikap toleransi dicontohkan oleh Rakai Panangkaran raja Kerajaan Mataram Kuno. 
Berdasarkan Prasasti Kalasan Raja Panangkaran membangun kuil untuk Dewi Tara. Menurut genealogi Sanjaya dia adalah anak lelaki Sanjaya, seorang raja Jawa yang memerintah Jawa Tengah pada 732 M. Hal yang menarik adalah bahwa Panangkaran yang dikaitkan melalui Sanjaya dijelaskan sebagai "penghias dari Dinasti Sailendra" (Munoz, 2009). Rakai Panangkaran yang beragama Hindu membangun kuil (candi) untuk agama Buddha yang memuja Dewi Tara. Kebijakan raja tersebut mencerminkan bahwa di Kerajaan Mataram Kuno telah ada toleransi beragama.

\section{Kesetaraan Gender}

Kesetaraan gender adalah kondisi di mana perempuan dan laki-laki menikmati status yang setara dan memiliki kondisi yang sama untuk mewujudkan secara penuh hak-hak asasi dan potensinya bagi pembangunan di segala bidang kehidupan (Puspitasari, 2012). Kesetaraan gender berdasarkan definisi tersebut menyatakan bahwa laki- laki dan perempuan memiliki hak sama dan setara dalam segala bidang kehidupan. Salah satu wujud dari kesetaraan gender dapat dilihat dalam bidang pemerintahan. Laki-laki dan perempuan dalam bidang pemerintahan memiliki kedudukan atau peran yang sama dalam menduduki posisi jabatan tertentu.

Kesetaraan gender telah dikenal dalam sejarah Kerajaan Mataram Kuno abad VIII-X Masehi. Berdasarkan sumber prasasti dapat diketahui adanya perempuan yang memiliki jabatan setara dengan laki-laki. Jabatan tersebut berada pada tingkat pemerintahan wanua. Perempuan yang menduduki jabatan tingkat wanua dapat diketahui berdasarkan Prasasti Kwak I dan Mulak I. Berikut merupakan kutipan prasasti yang menyebutkan pejabat perempuan.

Prasasti Kwak I Tahun 801 Saka IB Baris 3

...3.han ragi yu 1 soway soway // marhyay ${ }^{\circ} i$ kabiku ${ }^{\circ} a n$ si lanah si bhāryyā re watī / tuha paḍahi si dhanam / maregay 
si śukla / manila si buddha / madā $\eta .$.

Terjemahan ...3.sepasang kain untuk lelaki jenis Ragi // (pejabat) Marhyan di Kabikuan bernama Si Lanah Si Bhāryyā ibu dari [re] Watī / (pejabat) Tuha Paḍahi bernama Si Dhanam / (pejabat) Maregang Si Śukla / (pejabat) Mangla bernama Si Buddha / (pejabat) Madāng (Wurjantoro, 2018: 347).

Prasasti Mulak I Tahun IIIABaris 3 ...3.yu $1 \mathrm{so}^{\circ} \mathrm{a \eta} \mathrm{so}^{\circ} \mathrm{a \eta}$. huler 2 si tahun rama ni yukti. si tajam rama ni danī. tuhâlas sy-amwari re harì hulu wras 2 si wanu ${ }^{\circ} a . .$.

Terjemahan ...3.kain untuk lelaki jenis Rañga. Pejabat pengairan [huler] dua orang yaitu Si Tahun bapak dari Yukti, Si Tajam bapak dari Danī, Pangawas hutan [tuha alas] bernama si Amwarī ibu [re] dari Harī, Pejabat pertanian [hulu wras] dua orang yaitu Si Wanua...(Wurjantoro, 2018: 337).

Berdasarkan Prasasti Kwak I terdapat jabatan marhyay yang dijabat oleh perempuan. Pejabat tersebut bernama Si Bhāryyā ibu Watī. Berdasarkan Prasasti Mulak I terdapat jabatan tuha alas atau pengawas hutan yang dijabat oleh perempuan. Pejabat tersebut bernama si Amwarī ibu dari Harī. Keberadaan pejabat tingkat wanua yang dijabat oleh perempuan menunjukkan bahwa perempuan pada masa Kerajaan Mataram Kuno sudah memiliki kedudukan yang setara dengan laki-laki. Kedudukan tersebut terlihat dari keberadaan perempuan yang menjadi pejabat tingkat wanua.

Jabatan marhyay dan tuha alas pada masa Kerajaan Mataram Kuno dapat dijabat oleh seorang laki-laki dan perempuan. Jabatan dalam pemerintahan yang dapat dijabat oleh seorang perempuan menunjukkan bahwa di kerajaan tersebut sudah terdapat kesetaraan gender. Perempuan dan laki-laki memiliki kedudukan dan kesempatan yang sama dalam bidang pemerintahan. Masyarakat pada waktu itu sudah mengenal konsep kesetaraan gender. Keberadaan kesetaraan gender pada masa Kerajaan Mataram Kuno dapat digunakan sebagai sumber pembelajaran karakter pada pembelajaran sejarah.

\section{PENUTUP}


Berdasarkan sejarah Kerajaan Mataram Kuno abad VIII$\mathrm{X}$ Masehi dapat diketahui corak pendidikan dan nilai pendidikan karakter. Corak pendidikan masa Mataram Kuno adalah pendidikan berbasis keagamaan. Hasil pendidikan tersebut adalah kemampuan untuk membangun bangunan suci dan penanggalan. Nilai pendidikan karakter yang dapat dipelajari dari sejarah Kerajaan Mataram Kuno adalah local genius, toleransi, dan kesetaraan gender. Local genius dapat diketahui berdasarkan kemampuan masyarakat Nusantara (Mataram Kuno) untuk mengolah unsur budaya asing agar sesuai dengan budaya setempat. Contoh pengaruh asing yang disesuaikan dengan budaya setempat adalah bangunan candi. Toleransi dapat diketahui berdasarkan bangunan candi bercorak Hindu dan Buddha yang dibangun dengan jarak berdekatan. Kesetaraan gender berupa keberadaan pejabat perempuan yang menduduki jabatan tingkat wanua (desa).

\section{UCAPAN TERIMA KASIH}

Terima kasih penulis ucapkan kepada.

1. Program Studi Pendidikan Sejarah UNY

2. Museum Nasional Jakarta

3. Balai Pelestarian Cagar Budaya Jawa Tengah

4. Balai Arkeologi Daerah Istimewa Yogyakarta

5. Pemerintah Kabupaten Magelang

\section{DAFTAR PUSTAKA}

Hasan , S. Hamid. (2012). "Pendidikan Sejarah untuk Memperkuat Pendidikan Karakter". Jurnal Paramita, Volume, 22 Nomor, 1 Januari 2012, hlm. 81-95.

Khalikin, Ahsanul \& Fathur (Ed). (2016). Toleransi Beragama di Daerah Rawan Konflik. Jakarta: Puslitbang Kehidupan Beragama Kementerian Agama RI.

Kuntowijoyo. (2013). Pengantar Ilmu Sejarah. Yogyakarta: Tiara Wacana.

Munandar, Agus Aris. (2015). Keistimewaan Candi-Candi Zaman Majapahit. Jakarta: Wedatama Widya Sastra. 
Munoz, Paul Michel. Terjemahan Adve. (2009). KerajaanKerajaan Awal Kepulauan Indonesia dan Semenanjung Malaysia. Yogyakarta: Mitra Abadi.

Sedyawati, Edi, M. Zainuddin, Edhie Wuryantoro. (1991). Sejarah Pendidikan di Indonesia Sebelum Kedatangan Bangsa-Bangsa Barat. Jakarta: Departemen Pendidikan dan Kebudayaan.

Soebadio, Haryati. (1986)."Kepribadian Suatu Bangsa". Dalam Ayatrohaedi (Ed). Kepribadian Budaya Bangsa (Local Genius). Jakarta: Dunia Pustaka Jaya, hlm. 18-25.

Soejono, R.P. (1986). "Local Genius dalam Sistem Teknologi Prasejarah". Dalam Ayatrohaedi (Ed). Kepribadian Budaya Bangsa (Local Genius). Jakarta: Dunia Pustaka Jaya, hlm. 130-140.

Soekmono. (1973). Sejarah Kebudayaan Indonesia 2. Yogyakarta: Kanisius.

Setiawati, Nanda Ayu. (2017). "Pendidikan Karakter Sebagai Pilar Pembentukan Karakter Bangsa". Prosiding Seminar Nasional Tahunan Fakultas Ilmu Sosial Universitas Negeri Medan
Tahun 2017 Vol. 1 No. 1 2017, hlm. 348-352.

Puspitawati, Herien. (2015). "Pengenalan Konsep Gender, Kesetaraan dan Keadilan gender". Makalah Rapat Koordinasi Kesetaraan Gender se Wilayah 1 Bogor Kamis, 22 Maret 2012. Bogor: Departemen Ilmu Keluarga dan Konsumen, Fakultas Ekologi Manusia, Institut Pertanian Bogor, hlm. 1-19.

Wirasanti, Niken. (1997). "Masyarakat Jawa Kuna: Usaha Mendewasakan Diri Melalui Pendidikan dan Pengajaran. Dalam Cinandi. Yogyakarta: Jurusan Arkeologi Fakultas Sastra Universitas Gadjah Mada, hlm. 226-229.

Wurjantoro, Edhie. (2012). Prasasti Berbahasa Jawa Kuno Abad VIII - X Masehi Bukan Koleksi Museum Nasional Alihaksara dan Terjemahan. Depok: Departemen Arkeologi Fakultas Ilmu Pengetahuan Budaya Universitas Indonesia.

(2018). Anugerah Sri Maharaja: Kumpulan Alihaksara dan Alihbahasa Prasasti-Prasasti Jawa Kuna dari Abad VIII-IX. Depok: Departemen Arkeologi Fakultas Ilmu Pengetahuan Budaya Universitas Indonesia. 